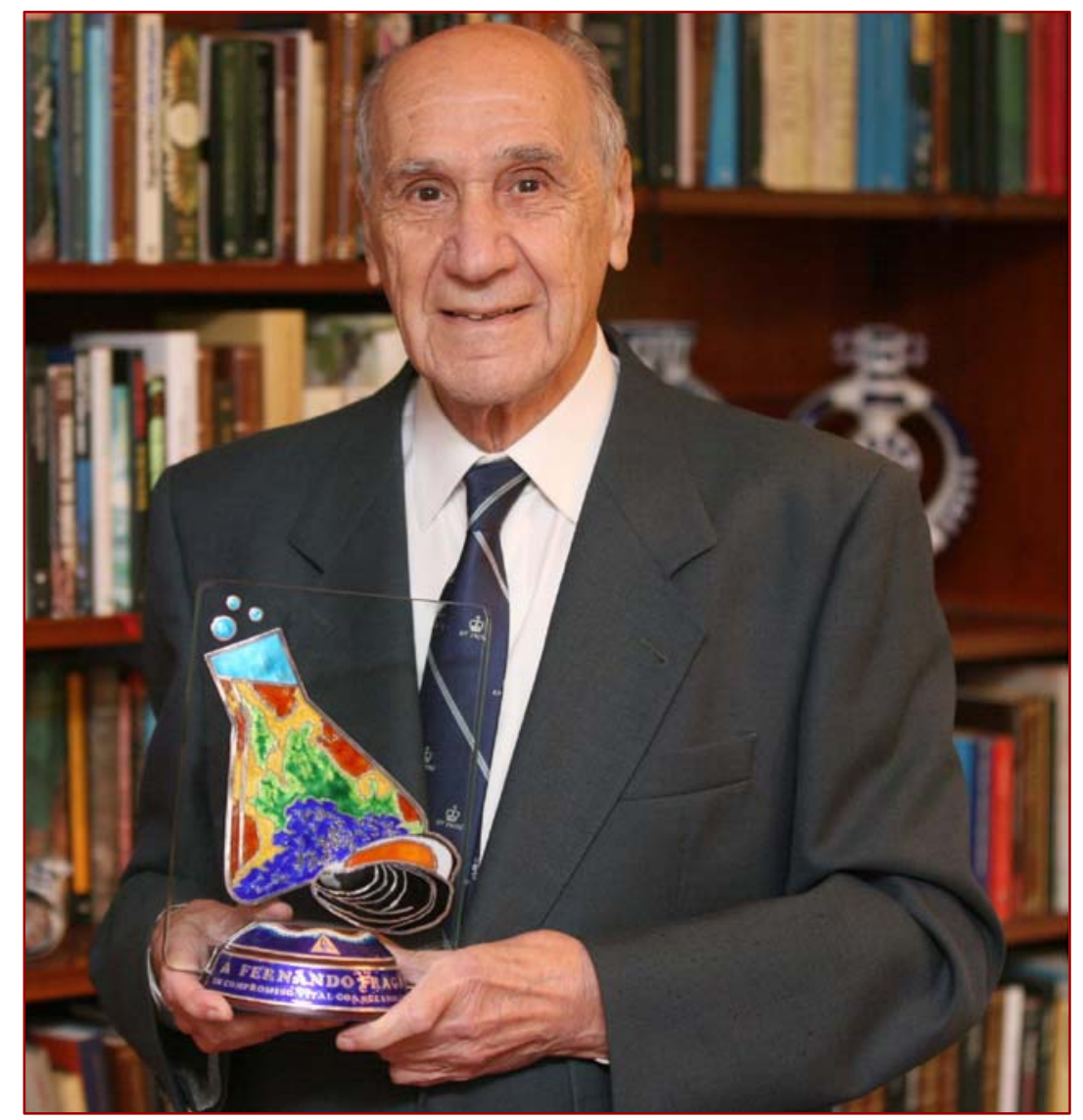

\title{
Fernando Fraga:
}

A living commitment to oceanography / Un compromiso vital con la oceanografía

This special issue is dedicated to Professor Dr. Fernando Fraga in recognition of his outstanding contribution to the field of marine chemistry, mainly focused on water mass variability, the nitrogen cycle, and organic matter in the oceans. Without a doubt, he is the pioneer of oceanography in Galicia, and the founder of oceanography and marine chemistry in Spain as they exist today. The accumulated experience of Fernando Fraga in chemical oceanography prepared him for the leadership of several scientific expeditions to the Indian Ocean, off northwest Africa, and off the northwest Iberian Peninsula. These oceanographic surveys were prolific in terms of publications and one should highlight Dr. Fraga's article in the 1981 American Geophysical Union Coastal Upwelling volume where he describes the water mass front located off Cape Finisterre that has been known ever since as Fraga's Front. That was the first time he analyzed the deep waters adjacent to the shelf, which he showed supply nutrients to the Galician Rías. This recirculating process generates an extra input of nutrients that maintains the synthetic activity of the Rías and inner zones of the Galician shelf. This process has been found to be quite
Este número especial está dedicado al Profesor Dr. Fernando Fraga en reconocimiento a sus sobresalientes contribuciones al campo de la química marina, centrado principalmente en la variabilidad de las masas de agua, el ciclo del nitrógeno y la materia orgánica en los océanos. Sin duda alguna, él es el pionero de la oceanografía en Galicia, y el germen de lo que actualmente son la oceanografía y la química marina en España. La experiencia acumulada de Fernando Fraga en oceanografía química le proporcionó el liderazgo de varias expediciones científicas en el Océano Indico, el noroeste de África y el noroeste de la Península Ibérica. Estos estudios oceanográficos fueron muy prolíficos en términos de publicaciones y, entre éstas, cabe destacar el artículo del Dr. Fraga publicado en 1981 en el volumen Coastal Upwelling de la American Geophysical Union, en el que describe el frente de masas de agua ubicado cerca del Cabo Finisterre que, desde entonces, ha sido conocido como el Frente de Fraga. Ésta fue la primera vez que se analizaron las aguas profundas adyacentes a la plataforma que suministran nutrientes a las rías, proceso de recirculación que genera una entrada extra de nutrientes que sustentan la gran 
common in other upwelling systems. Fernando Fraga has also contributed greatly to the ocean science community as a member of several scientific panels and as scientific editor of several journals. The excellence of his scientific trajectory has been recognized by several awards. His scientific legacy of five decades may be found in: http://oceano.iim.csic.es/ xv_seminario_quimica_marina/legado-cientifico/. Those scientists who have had the pleasure of interacting with Fraga have benefited greatly from his teaching and enthusiastic sharing of his knowledge and ideas. Dr. Fraga is an outstanding scientist, bestowed with qualities of kindness and humility. He has always been a pioneer in the use of new technologies. His open-mindedness and commitment to science constitutes a model to follow and an unquestionable guide for all of us. actividad sintética de las Rías y zonas interiores de la plataforma gallega. Este proceso es bastante recurrente en otros sistemas de afloramiento. Fernando Fraga también ha contribuido en gran medida a la comunidad de las ciencias del mar, como miembro de varias comisiones científicas y como editor de varias revistas científicas. La excelencia de su trayectoria científica ha sido reconocida con varios premios. Su legado científico de cinco décadas se puede encontrar en: http://oceano.iim.csic.es/xv_seminario_quimica_marina/ legado-cientifico/. Los científicos que hemos tenido el placer de interactuar con Fraga nos hemos beneficiado enormemente de sus enseñanzas y entusiasmo para compartir sus conocimientos e ideas. El Prof. Fraga es un destacado científico con bondad y humildad que siempre ha sido un pionero en el uso de nuevas tecnologías. Su amplitud de miras y compromiso con la ciencia constituye un modelo a seguir y una guía indiscutible para muchos de nosotros.

Aida F Ríos, Eric D Barton, and Fiz F Pérez

Instituto de Investigaciones Marinas, CSIC, Vigo, Spain 